\title{
Contribution of galvanic vestibular stimulation for the diagnosis of HAM/TSP
}

\author{
Luciana Cunha ${ }^{1,2}$, Ludimila Labanca ${ }^{1,2}$, Anna Bárbara F Carneiro-Proietti ${ }^{1,3}$, Lucas N Carvalho², \\ Daniele R Fernandes ${ }^{2}$, Ana Lúcia B Starling ${ }^{1,2}$, Denise U Gonçalves ${ }^{1,2^{*}}$ \\ From 16th International Conference on Human Retroviruses: HTLV and Related Viruses \\ Montreal, Canada. 26-30 June 2013
}

\section{Introduction}

Galvanic vestibular stimulation (GVS) is a low-cost and safe exam that tests the vestibulospinal pathway. HTLV1-associated myelopathy/tropical spastic paraparesis (HAM/TSP) is a slowly progressive disease that precociously affects the vestibulospinal tract. This study compared electromyographic (EMG) responses triggered by GVS between asymptomatic individuals infected with HTLV-1 and those with HAM/TSP.

\section{Methods}

Bipolar galvanic stimuli of $400 \mathrm{~ms}$ and $2 \mathrm{~mA}$ intensity were applied on the mastoid processes in 120 trials. The EMG response, and its short latency (SL) and middle latency (ML) components, was recorded from both soleus muscles in 13 healthy, HTLV-1-negative adults (56 \pm 5 years, mean $\pm \mathrm{SD}$ ), and 26 individuals infected with HTLV-1, 13 asymptomatic (56 \pm 8 years) and 13 with HAM/TSP ( $60 \pm 6$ years).

\section{Results}

The average value of EMG components in the group of healthy individuals was $55 \pm 4 \mathrm{~ms}(\mathrm{SL})$ and $112 \pm 10 \mathrm{~ms}$ (ML); in the group of asymptomatic HTLV-1 carriers, $61 \pm 6 \mathrm{~ms}(\mathrm{SL})$ and $112 \pm 10 \mathrm{~ms}(\mathrm{ML})$; and in the group with HAM/TSP, $67 \pm 8 \mathrm{~ms}$ (SL) and $130 \pm 3 \mathrm{~ms}$ (ML) $(\mathrm{P}=0.001)$. In the HTLV-1-asymptomatic group, the $\mathrm{SL}$ component was delayed in 4/13 (31\%) exams and the ML component was normal in all. In the HAM/TSP group, the most common alteration was the absence of waves.

\section{Conclusion}

A pattern of abnormal vestibular-evoked EMG response was found in the HTLV-1-neurological disease, which ranged from delayed latency among asymptomatic carriers to absence of response in HAM/TSP. GVS may contribute to early diagnosis and monitoring of nontraumatic myelopathies.

\section{Authors' details \\ ${ }^{1} H T L V$ Interdisciplinary Research Group (HTLV-1), Belo Horizonte, Minas Gerais, Brazil. ${ }^{2}$ Tropical Medicine Post Graduation Program, Faculty of Medicine, Federal University of Minas Gerais, Belo Horizonte, Minas Gerais, Brazil. ${ }^{3}$ Foundation and Center for hematology and hemotherapy of Minas Gerais, Belo Horizonte, Minas Gerais, Brazil.}

Published: 7 January 2014

doi:10.1186/1742-4690-11-S1-P27

Cite this article as: Cunha et al:: Contribution of galvanic vestibular stimulation for the diagnosis of HAM/TSP. Retrovirology 2014 11(Suppl 1): P27.

\footnotetext{
* Correspondence: deniseg@medicina.ufmg.br

${ }^{1}$ HTLV Interdisciplinary Research Group (HTLV-1), Belo Horizonte, Minas Gerais, Brazil

Full list of author information is available at the end of the article
}

Submit your next manuscript to BioMed Central and take full advantage of:

- Convenient online submission

- Thorough peer review

- No space constraints or color figure charges

- Immediate publication on acceptance

- Inclusion in PubMed, CAS, Scopus and Google Scholar

- Research which is freely available for redistribution

Submit your manuscript at www.biomedcentral.com/submit
() Biomed Central 